\title{
PEMAHAMAN MASYARAKAT TENTANG KORUPSI
}

\author{
RB. Soemanto, Sudarto, Sudarsana \\ Jurusan Sosiologi, Fakultas IImu Sosial dan IImu Politik \\ Universitas Sebelas Maret Surakarta \\ e-mail : Soemanto_rb@yahoo.com
}

\begin{abstract}
The National Development of Indonesia aimed to improve people's welfare based on social justice. Transparency International survey (STI) stated Indonesia is one of the top corruption countries in the world. Corruption has been widespread and carried out by all elements of society, including public officials (Djulianto, 2009). The government of Indonesia combat to corruption by implementing Anti coruption Act, the government also building The commission for combating corruption to enforce the execution of corruption eradication program. Effectiveness execution of the program need contribution of community participation. Research question is: "how do community understand and responding to corruption?". This research use combination of quantitative and qualitative method of data collection. Locations of research are the District of Klaten, Surakarta and Sragen. Area samples of the research are: the Village of Kedungan from Klaten district; gabugan from District of Sragen, and Kerten from the Municipality of Surakarta. The sample of respondents are systematically selected by proportional random sampling technique. The quantitative data are collected by structured interviewing techniques. These data are analyzed by applying correlation technique. Qualitative data are collected by using depth interview and FgD technique; analysis of the data apply descriptive qualitative methods. combination of quantitative and qualitative data analysis are executed to get a complementary of final data. Results of research showed that the villagers from the district of Klaten, Surakarta and Sragen have knowledge, attitude and a heightened awareness of the corruption that cost the state and society. The characteristics of corruption, resources and its consequences are well understood. X2 test result by 19,12 and sigificant at 99\% confidence level (0.01 alpha). The Correlation between response and attitudes towards corruption is significantly stated (coefficient contingensi 0,247), at 0.01 alpha. Means, that the corelation between attitudes and corruption also significantly response (rs coefficient of 0.301 ) at the $99 \%$ confidence level (0.01 alpha). corruption as an improper act, the more people oppose it, the greater the support for the government's efforts to combat corruption. Rate $R$ of 0.552 shows the correlation between the response to the level of knowledge, attitude, and it has significantly levels of consciousness. Generally stated that the community has knowledge of corruption, great attitude and awareness as well as having a positive response to support the (government) to eradicate corruption.
\end{abstract}

Keywords: Knowledge, Attitudes, Awareness, Response, Eradication to corruption

\begin{abstract}
Abstrak
Pembangunan Nasional Indonesia bertujuan untuk meningkatkan kesejahteraan masyarakat berdasarkan keadilan sosial. Survei Transparency International (TI) menyatakan Indonesia merupakan salah satu negara paling korup di dunia. Korupsi telah meluas dan dilakukan oleh semua elemen masyarakat, termasuk pejabat publik (Djulianto, 2009). Pemerintah Indonesia memerangi korupsi dengan menerapkan Undang-Undang Antikorupsi, di samping membangun Komisi Pemberantasan Tindak Pidana Korupsi (KPK) untuk menegakkan pelaksanaan program pemberantasan korupsi. efektivitas pelaksanaan program membutuhkan kontribusi dari partisipasi masyarakat.

Pertanyaan penelitian adalah: "bagaimana masyarakat memahami dan menanggapi korupsi?" Pertanyaan penelitian : "bagaimana pengetahuan, sikap, kesadaran dan respon masyarakat terhadap korupsi ?". Penelitian ini menggunakan metode gabungan kuantitatif dan kualitatif dalam pengumpulan data. Lokasi penelitian di Kabupaten Klaten, Kabupaten Sragen dan Kota Surakarta. Sampel wilayah kabupaten/kota terpilih desa sampel : Kedungan, Kecamatan Pedan di Kabupaten Klaten, desa Gabugan, Kecamatan Tanon, Kabupaten Sragen, dan Kelurahan Kerten, Kecamatan Laweyan, di Kota Surakarta. Sampel renponden dari desa/kelurahan ditentukan secara sistematik proporsional random, masing-masing desa terpilih 100 orang. Pengumpulan data kuantitatif digunakan teknik wawancara terstruktur. Analisis
\end{abstract}


data kuantitatif dilakukan dengan teknik korelasi. Data kualitatif dikumpulkan dengan teknik wawancara mendalam dan FGD. Hasil analisis data kuantitatif dan kualitatif dibahas bersama untuk mendapatkan data yang saling melengkapi. Hasil penelitian menunjukkan bahwa masyarakat desa di Kabupaten Klaten, Sragen serta kota Surakarta memiliki pengetahuan, sikap dan kesadaran yang tinggi tentang tindak korupsi yang merugikan negara dan masyarakat. Ciri-ciri tindak korupsi, sumber dan akibatnya dipahami dengan baik dan lengkap. Hasil uji $X^{2}$ sebesar 19, 115 dan sigifikan pada taraf kepercayaan 99\% (alpha 0,01 ). Hubungan sikap dengan tanggapan terhadap tindak korupsi dengan koefisien contingensi 0,247 , signifikan pada alpha 0,01.Artinya, hubungan sikap dengan respon terhadap tindak korupsi memiliki koefisien korelasi (rs) 0,301 dan signifikan pada tingkat kepercayaan 99\% (alpha 0,01). Korupsi sebagai perbuatan tidak benar, semakin masyarakat menentangnya semakin mendukung upaya pemerintah untuk memberantas korupsi. Angka $R$ sebesar 0,552 menunjukkan bahwa korelasi antara respon masyarakat dengan tingkat pengetahuan, sikap, dan tingkat kesadaran adalah kuat. Artinya, secara umum dinyatakan bahwa masyarakat memiliki pengetahuan mengenai korupsi, sikap dan kesadaran yang besar serta memiliki respon positif untuk mendukung upaya (pemerintah) menanggulangi korupsi.

Kata kunci : Pengetahuan, Sikap, Kesadaran, Respon, Pemberantasan Korupsi

\section{A. Pendahuluan}

Perubahan sosial sebagai proses pembangunan nasional yang terencana oleh pemerintah bertujuan untuk memperbaiki kehidupan rakyat dan masyarakat Indonesia. Perbaikan kehidupan sosial, ekonomi, politik dan bidang lainnya dilaksanakan untuk mewujudkan kesejahteraan rakyat yang berkeadilan sosial. Pemerintah menjalankan program-program sebagai penjabaran kebijakan publik dan melibatkan seluruh jajaran aparat birokrasi pemerintah, didukung partisipasi masyarakat dan segenap unsur organisasi social. Partisipasi masyarakat berpengaruh positif bagi peningkatan atau perbaikan kualitas hidup rakyat secara proporsional dan berkeadilan sosial.

Pemerintah Indonesia melibatkan seluruh jajaran institusi birokrasi dan segenap aparatur untuk menggerakkan perubahan sosial mewujudkan cita-cita di atas. Faktor hukum (peraturan perUndang-Undangan) melandasi langkah-langkah seluruh pelaksanaan program. Faktor internal dan eksternal yang hadir mendinamisasi peran masyarakat dalam pelaksanaan program-program pembangunan.

Korupsi adalah realitas tindakan penyimpangan norma sosial dan hukum yang tidak dikehendaki masyarakat dan diancam sanksi oleh negara. Korupsi sebagai bentuk penyalahgunaan kedudukan (jabatan), kekuasaan, kesempatan untuk memenuhi kepentingan diri sendiri dan atau kelompoknya yang melawan kepentingan bersama (masyarakat).

Indonesia berada dalam satu posisi penguasaan trihibrid, tiga aspek yang berbeda sifatnya: yaitu politik, hukum dan korupsi yang menyatu. Jika $10-20$ tahun ke depan, satu negara dipimpin oleh barbarian modern: birokrasi

Yustisia Vol. 3 No. 1 Januari - April 2014 korup, politisi busuk, pengacara hitam, dan pengusaha kapitalistik; Negara itu akan runtuh (Adjie Suradji, Kompas, Sabtu 13 Oktober 2012). Upaya Pemerintah Indonesia menanggulangi korupsi dilakukan dengan memberlakukan Undang-Undang Nomer 30 Tahun 2005 tentang Penanggulangan Korupsi.

Secara atomistik, tindak korupsi merebak di lingkar oligarkhi kekuasaan, karena: (1) tidak ada kompetensi teknis moral, dan (2) pemimpin menjadi patron kejahatan (dalam J. Chambliss ' Criminal Law in Action). Korupsi merupakan konstruksi sosial bersifat struktural, dan diduga korupsi kalangan masyarakat bawah sebagai konstruksi sosial terkait pengaruh korupsi kalangan masyarakat atas (elite sosial ekonomi), misalnya: pemimpin dan tokoh masyarakat lainnya).

Beny Murdani (1932-2004) menyatakan bahwa penghayatan perjuangan masa lalu dan sekarang berbeda. Generasi saat ini adalah generasi masa damai yang tidak mengalami masa revolusi kemerdekaan. Mereka lebih profesional karena memperoleh pendidikan dan pelatihan secara akademik, namun kurang memiliki tanggung jawab bersama. Oleh sebab itu, negeri ini tidak lagi melahirkan pemimpin sejati.

Sebuah pohon bisa dikenali dari buahnya. Sedangkan karakter bangsa bisa dilihat dari kualitas hukum dan kredibilitas pemimpinnya. Selanjutnya dinyatakan bahwa jika semakin banyak produk hukum dibuat, makin mempertegas anggapan bahwa tindak korupsi makin besar dan meluas. Maka dari itu, implementasi bentuk tanggung jawab pemimpin wajib dilaksanakan dengan tegas dan jelas dalam memelopori usaha pemberantasan korupsi.

Penilaian itu lazim, karena perilaku korupsi telah berkembang dan menjalar ke segala segi dan lapisan masyarakat, dan dilakukan oleh pejabat 
publik serta hampir seluruh unsur masyarakat (Djulianto, 2009). Tindakan korupsi berkembang di tingkat individu, lembaga (organisasi) dan kelompok sosial.

Gambaran di atas menunjukkan bahwa proses pelaksanaan pembangunan terganggu oleh praktek korupsi para pejabat pemerintah dan penyelenggara negara. Pemerintah berusaha untuk memberantasnya, dan membutuhkan partisipasi masyarakat. Upaya penanggulangan korupsi dilakukan juga oleh organisasi sosial tertentu seperti ICW (Indonesian corruption watch). Warga masyarakat belum I tidak mengorganisir peranannya mendukung pemerintah menanggulangi korupsi. Kesadaran dan respon masyarakat terhadap korupsi belum jelas diketahui peta sebaran dan keadaannya. Maka penelitian ini dilakukan dengan focus permasalaha : "bagaimana sikap, kesadaran dan respon masyarakat terhadap tindak korupsi?"

\section{B. Metode Penelitian}

Kajian ini berfokus pada konstruksi masyarakat tentang korupsi sebagai realitas sosial berkenaan dengan tingkat pengetahuan, sikap \& kesadaran dan responnya terhadap korupsi. Konstruksi masyarakat tentang korupsi itu sebagai modal sosial dalam praktek pengembangan untuk membantu dan mendukung pemerintah dan semua pihak (institusi) dalam upaya pemberantasan korupsi di Indonesia.

\section{Jenis}

Penelitian ini menggunakan jenis penelitian deskriptif eksploratif dan eksplanatif. Subyek penelitian terdiri dari individu dalam keluarga dan kelompok sosial lainnya. Objek penelitian mencakup pengetahuan, sikap, kesadaran masyarakat, dan respon warga masyarakat terhadap tindak/perbuatan korupsi. Pandangan dan perilaku tokoh masyarakat dieksplorasi terkait meluasnya tindak korupsi. Dari data itu dikonstruksi pemahaman masyarakat menurut perbedaan dan kesamaan pengetahuan, sikap, kesadaran dan respon mereka terhadap tindak korupsi.

2. Sifat

Penelitian ini dilakukan dengan 'rancangan metode campuran (gabungan) paralel', bersifat kualitatif dan kuantitatif. Keduanya digunakan bersama-sama, dan dilakukan dalam kajian secara bersamaan. Penelitian dilakukan di tiga lokasi (dua desa dan satu kelurahan),. Sifat pendekatan kualitatif dan kuantitatif digunakan bersamasama dalam pengumpulan data dengan teknik analisisnya masing-masing. Hasil analisis data itu bersifat saling melengkapi.

Dalam proses pelaksanaan, penelitian kualitatif mendukung proses penelitian kuantitatif, begitu sebaliknya penelitian kuantitatif memfasilitasi proses penelitian kualitatif. Keduanya mendapatkan bobot sama dan bersifat triangulatif dalam analisis data (Bryman, 2010); dan kedua pendekatan itu diterapkan dalam penelitian.

Metode survei menerapkan landasan ilmiah untuk mempelajari dan mengatasi masalah sosial dan keadaan pada wilayah tertentu, serta memberikan rekomendasi bagi upaya tindak lanjut. Survei ini biasanya dilakukan untuk mempersiapkan programprogram pembangunan dan menghilangkan hambatan atau gangguan sosial, serta pengumpulan data dasar bagi penelitian sosial lebih lanjut.

\section{3. data, Teknik Pengunpulan data}

Teknik area sampling menetapkan lokasi penelitian di Kabupaten Klaten dan Sragen serta di Kota Surakarta, dan masing-masing dipilih Desa Kedungan, Kecamatan Pedan, Klaten; Desa Gabugan, Kecamatan Tanon, Sragen, dan Kelurahan Kerten, Kecamatan Laweyan, Kota Surakarta. Dari masingmasing desa/kalurahan dipilih 3 dusun, atau 3 Rukun Warga (RW).

Objek penelitian adalah data tentang pengetahuan, sikap, kesadaran masyarakat, dan respon warga masyarakat terhadap tindak/perbuatan korupsi. Pandangan dan perilaku tokoh masyarakat terkait meluasnya tindak korupsi. Berdasarkan hasil analisis data dilakukan konstruksi pemahaman masyarakat menurut pengetahuan, sikap, kesadaran dan respon mereka terhadap tindak korupsi.

Teknik sampel penelitian campuran diadaptasi dari model Onwuegbuzie dan Collins (2010). Sampel responden dipilih 100 kepala keluarga secara random, dilakukan dengan interval 15, dipilih 1 orang dari setiap 15 orang populasi. Sadangkan penelitian kualitatif dilakukan secara purposisive

Teknik pengumpulan data survey dilakukan dengan wawancara terstruktur pada responden. Teknik FGD dilakukan terhadap wakil warga; dan pada pemuka masyarakat digunakan teknik wawancara mendalam. Pengumpulan data dengan FGD dan wawancara mendalam sebagai crosschecking data survey. 
Analisis data kuantitatif menggunakan teknik korelasi Tata Jenjang Spearman. (rho yang diberi simbul $\rho$ ) untuk mengukur asosiasi dua variabel berskala ordinal yang memungkinkan individu yang diteliti dapat diberi jenjang (ranking). Chi Square untuk membandingkan kelompok-kelompok yang diamati dengan yang diharapkan,

Korelasi multivariate untuk melihat hubungan tingkat pengetahuan, sikap, dan tingkat kesadaran dengan respon terhadap korupsi. Teknik penghitungannya dilakukan dengan bantuan program SPSS versi 17.0 melalui sub menu regresi. Analisa data kualitatif dilakukan secara deskriptif komparatif melalui proses triangulasi data, hasilnya untuk mendukung analisa dan pembahasan data kuantitatif. Data kuantitatif dan kualitatif digunakan untuk saling melengkapi dalam analisis data dan pembahasan hasil penelitian.

\section{Hasil Penelitian dan Pembahasan}

Perilaku manusia tidak dapat terlepas dari keadaan individu orang itu sendiri dan lingkungan sosial (masyarakatnya). Perilaku individu merupakan tindakan berulang dalam waktu tertentu dan didorong oleh motif tertentu sehingga ia berperilaku sosial tertentu. Hasil penelitian mengenai tingkat pengetahuan, sikap, kesadaran, dan respon/tanggapan masyarakat terhadap perbuatan korupsi dinyatakan berikut ini.

\section{Hasil Penelitian}

Secara umum pengetahuan masyarakat tentang korupsi yang berkembang saat ini bersumber dari jalur media massa, yaitu siaran pemberitaan di TV, siaran radio dan pemberitaan di Surat kabar $(67,4 \%)$. Sumber pengetahuan tentang korupsi dari komunikasi horizontal (saudara/family, tetangga dan teman) dan sumber dari media massa tersebut tercatat $77,6 \%$. Seluruh responden $(n=294)$ dari penelitian ini menyatakan tahu, mengerti tentang korupsi di Indonesia. Rincian hasil penelitian dikemukakan sebagai berikut:

1. Sikap masyarakat terhadap perbuatan korupsi tercatat $46,9 \%$ yang tidak memuji atau membencinya. Mereka yang menyatakan tidak tahu bagaimana bersikap pada perbuatan korupsi sebesar 46,3\%; bahkan tercatat sebesar $6,8 \%$ masyarakat (responden) yang menerima, bersikap mendukung perbuatan korupsi.
Jadi realitasnya masih ditengarai sikap pro dan kontra terhadap perbuatan korupsi di masyarakat.

2. Dari aspek kesadaran masyarakat, ditemukan realitas bahwa $75,2 \%$ responden menganggap jika perbuatan korupsi tidak dilakukan tindakan tegas pemerintah dengan pengenaan sanksi berat, bisa merusak dan bahkan menghancurkan masyarakat serta melemahkan usaha mewujudkan kesejahteraan rakyat yang berkeadilan sosial.

3. Respon masyarakat terhadap perbuatan korupsi menunjukkan $72,1 \%$ yang menyatakan bahwa perbuatan korupsi diyakini merugikan masyarakat dan menguras kekayaan Negara. oleh karena itu dinyatakan:

a. Tindakan korupsi harus dihukum seberat-beratnya

b. Responden menyatakan 'siap' mendukung pemerintah dalam memberantas korupsi

c. Responden bersedia membantu pemerintah asal mendapat jaminan perlindungan

d. Responden tidak melakukan perbuatan berbau korupsi dalam kehidupan sehari-hari

e. Menanamkan pada keluarga (dan anak-anak) untuk selalu berbuat jujur

f. Responden dan masyarakatnya bersedia membantu menanggulangi korupsi.

\section{Pembahasan}

Teori-teori psikologi social dan teori sosiologi dikemukakan untuk membahas hasil penelitian tersebut.

a. Teori Dorongan (drive theory)

Teori ini berpandangan bahwa organisme (masyarakat dan individu) mempunyai dorongan-dorongan atau drive tertentu. Dorongan-dorongan ini berkaitan dengan kebutuhankebutuhan masyarakat dan ndividu yang mendorong terbentuknya perilaku. Bila masyarakat dan individu timbul kebutuhan (baru), kebutuhan itu bisa mendorong timbulnya ketegangan dalam hubungan sosial di masyarakat. Bila perilaku individu dan masyarakat dapat memenuhi kebutuhannya, maka terjadi 
pengurangan atau reduksi terhadap factor dorongan yang menimbulkan ketegangan (Walgito, 2002 : 17-18).

b. Teori Insentif (incentive theory)

Teori ini berpendapat bahwa perilaku individu dan masyarakat terjadi karena ada insentif yang mendorong masyarakat berbuat dan beperilaku tertentu. Insentif bersifat positif dan negatif, yang positif mendorong individu dan masyarakat merespon dengan perilaku, sedangkan yang negatif menghambat individu dan masyarakat berperilaku (Walgito, 2002 : 18).

Menurut George Ritzer (2003 : 73), terdapat teori-teori yang termasuk dalam paradigma perilaku sosial. Salah satunya adalah teori Sosiologi Perilaku (behavioral Sosiology) yang menekankan fungsi ganjaran sebagai penguat atau disebut reinforcement, dan Teori Pertukaran (exchange). Teori Perilaku Sosial menitikberatkan pada hubungan antara tingkah laku aktor/pelaku dengan tingkah laku lingkungannya. Konsep dasarnya adalah penerimaan ganjaran; ganjaran yang tidak berpengaruh terhadap tindakan aktor tidak akan berulang. Teori Pertukaran (exchange) menitikberatkan pemahaman bahwa manusia pada dasarnya tidak mencari keuntungan dari interaksi yang dilakukan dengan pihak (individu) dan kelompok lain.

Homans (dalam Poloma, 2003 : 61-65) mengklasifikasi perilaku sosial ke dalam lima pernyataan proposional:

a. Proposisi sukses

Dalam tindakan, semakin sering suatu tindakan memperoleh ganjaran, maka kian kerap tindakan itu dilakukan (diulang). Dalam proposisi ini Homans menyatakan bahwa bilamana seseorang berhasil memperoleh ganjaran (atau menghindari hukuman) maka ia akan cenderung untuk mengulangi tindakan tersebut ( dalam Poloma, 2003 : 61).

b. Proporsi Stimulus

Jika terjadi stimulus (pengetahuan, informasi) khusus, atau sejumlah stimuli, maka peristiwa dimana tindakan seseorang memperoleh ganjaran, semakin mirip dengan stimuli yang ada saat ini; seseorang akan melakukan, merespon tindakan serupa atau yang agak sama. Stimulus berhubungan secara fungsional dengan obyek, respon atau tindakan untuk memperoleh ganjaran yang diinginkan (dalam Poloma, 2003 : 62).

c. Proposisi Nilai

Semakin tinggi nilai suatu tindakan, maka kian senang seseorang melakukan tindakan itu. Proposisi ini khusus berhubungan dengan ganjaran atau hukuman yang merupakan hasil tindakan (dalam Poloma, 2003 : 63).

d. Proposisi Kejenuhan-Kerugian (deprivasisatiasi)

Semakin sering (pada saat ini atau saat yang baru berlalu) seseorang menerima suatu ganjaran, maka semakin kurang bernilai bagi orang tersebut sekalipun terjadi peningkatan ganjaran dari setiap tindakan itu (Poloma, 2003 : 63-64).

e. Proposisi Persetujuan-Perlawanan (Approval-agression)

Bila tindakan seseorang tidak memperoleh ganjaran yang diharapkannya, atau menerima hukuman yang tidak diinginkan, maka dia akan marah, dia menjadi sangat cenderung menunjukkan perilaku agresif, dan hasil perilaku demikian lebih bernilai baginya. Bilamana tindakan seseorang memeperoleh ganjaran yang diharapkannya, khusus ganjaran yang lebih besar dari yang diperkirakan, atau tidak memeperoleh hukuman yang diharapakannya, maka ia akan merasa senang, dan berperilaku atas hal yang disenanginya, dan hasil dari perilaku yang demikian akan menjadi lebih bernilai baginya (Poloma, 2003 : 64-65)

Perilaku dapat diartikan suatu respon seseorang terhadap rangsangan (pengetahuan, informasi) dari luar subjek tersebut. Perilaku diartikan sebagai suatu aksi-reaksi sosial terhadap lingkungannya. Perilaku terjadi apabila ada sesuatu yang diperlukan untuk menimbulkan reaksi, yang disini disebut rangsangan (pengetahuan, informasi). Rangsangan (pengetahuan, informasi) tertentu akan menghasilkan reaksi atau perilaku tertentu. Perilaku seseorang 
adalah aktivitas yang timbul karena adanya stimulus dan respons yang dapat diamati secara langsung dan tidak langsung.

Dari hasil penelitian di Desa Kedungan, Gabudan dan di Kerten diperoleh gambaran empiris bahwa semua warga masyarakat (100\%) mengetahui tentang ada dan merebaknya korupsi di masyarakat. Mereka sebagian besar $(<70 \%)$ mengerti beberapa sifat dari tindak korupsi dan faktor penyebabnya. Koruspsi adalah bentuk pengkhianatan kepercayaan masyarakat, menipu rakyat dan pemerintah, melalaikan kepentingan masyarakat, dilakukan sendiri dan lebih dari 1 orang. Pemahaman mereka tentang hal yang sama masih beragam; seperti : mencuri uang rakyat, mengambil kekayaan Negara, mencuri uang Rukun Tetangga, dan sebagainya.

Sikap masyarakat terhadap merebaknya tindak korupsi menunjukkan gambaran yang positif. Artinya, mereka cenderung tidak setuju (<60\%) terhadap pemberian sanksi hukum yang ringan pada koruptor, menolak sumbangan social yang berasal dari perbuatan korupsi, menolak membayar untuk masuk (bagi anak) menjadi pegawai negeri, menolak memberi uang (amplop) untuk mendapatkan perlakuan khusus, dan sebagainya.

Tingkat kesadaran masyarakat cukup tinggi $(<60 \%$ ) terhadap tindak korupsi yang umumnya dilakukan oleh pejabat Negara, pihak swasta bahkan oleh sebagian warga masyarakat; dan kalau tidak ditindak tegas dan diberantas secara sistemik korupsi akan makin besar dan menghancurkan kehidupan berbangsa, bernegara dan bermas yarakat.

Respon masyarakat terhadap usaha pemerintah untuk menanggulangi korupsi juga cukup besar. Hal ini terbukti respon masyarakat tercatat lebih dari $65 \%$. Respon itu dinyatakan berupa dukungan dan tindakan partisipatif terhadap upaya pemerintah untuk menanggulangi tindak korupsi; namun mereka membutuhkan jaminan perlindungan keselamatan dari pemerintah.

Test hubungan antara variable pengetahuan, sikap, dan kesadaran masing-masing dengan responnya terhadap usaha pemerintah maupun organisasi masyarakat dalam upaya penanggulangan korupsi; koefisien korelasinya sangat signifikan. Artinya, semakin tinggi pengetahuan seorang dalam masyarakat, sikapnya positif dan tegas dan kesadaran yang besar, mendorong tumbuhnya respon positif terhadap upaya penanggulangan korupsi.

Hasil analisis dan pembahasan hasil penelitian (di atas) dapat dinyatakan bahwa teori perilaku (proporsi stimulus, nilai, kejenuhan-kerugian, persetujuanperlawanan) mendukung analisis dan pembahasan hasil penelitian yang membahas pengetahuan, sikap, kesadaran masyarakat dan respon masyarakat terhadap tindak korupsi

Respon seseorang terhadap rangsangan (pengetahuan, informasi) dari luar subjek, sebagai suatu aksi-reaksi sosial terhadap lingkungannya. Perilaku (respon) terjadi apabila ada sesuatu yang diperlukan untuk bereaksi, yaitu rangsangan (pengetahuan, informasi). Rangsangan (pengetahuan, informasi) tertentu akan menghasilkan reaksi atau perilaku tertentu berupa sikap dan kesadaran. Perilaku (respon) seseorang adalah aktivitas yang timbul karena adanya stimulus yang dapat diamati secara langsung dan tidak langsung.

Pengetahuan masyarakat tentang tindak korupsi yang berkembang cepat, menimbulkan sikap menolak, karena merugikan kepentingan mereka (bersama), dan menumbuhkan kesadaran positif terhadap usaha-usaha menanggulanginya. Respon masyarakat bersedia mendukung dan membantu usaha pemerintah dalam program dan kegiatan penanggulangan korupsi. Respon positif tersebut akan dilakukan lebih-lebih jika mereka mendapatkan jaminan perlindungan keamanan dan keselamatan dari pemerintah.

\section{d. Simpulan}

Dari uraian tersebut di atas dapat dikemukakan simpulan sebagai berikut:

1. Perbuatan korupsi yang berkembang di lingkungan lembaga pemerintah dan oleh jajaran aparatur pemerintah telah diketahui oleh sebagian besar masyarakat. Warga masyarakat juga mengetahui ragam dan 
jenis kegiatan korupsi yang dilakukan oleh para pelakunya. Perbuatan korupsi yang juga dilakukan oleh anggota masyarakat dan oleh para pelaku usaha dan perdagangan telah diketahui juga oleh sebagian warga masyarakat. Warga masyarakat di pedesaan dan di perkotaan (di desa-desa dan kelurahan lokasi penelitian) tidak berbeda pengetahunnya tentang berkembang dan meluasnya korupsi

2. Sikap masyarakat (responden) terhadap perbuatan korupsi berupa sikap tidak simpati sampai dengan sikap antipati. Korupsi bersifat merugikan Negara dan masyarakat, melemahkan sendi-sendi kehidupan masyarakat, berbangsa dan bernegara. Korupsi dilakukan oleh orang, kelompok orang, pihak tertentu yang memperkaya diri, mencelakai kehidupan masyarakat, dan melemahkan solidaritas sosial karena menimbulkan kesenjangan sosial ekonomi yang makin besar di masyarakat. Masyarakat pedesaan maupun perkotaan memiliki sikap serupa terhadap tindak korupsi. Mereka menunjukkan sikap tidak setuju, membenci perbuatan korupsi yang pelakunya dihukum ringan, dan mengecam serta menolak bantuan/sumbangan yang diberikan koruptor dengan ke rumah jompo, panti asuhan, dan warga masyarakat miskin lainnya

3. Tingkat kesadaran dan persepsi masyarakat terhadap tindak korupsi yang berkembang sekarang ini menimbulkan keprihatinan warga masyarakat. Jika program penanggulangan korupsi tidak intensif dilakukan pemerintah, maka perbuatan korupsi akan meluas dan membahayakan kehidupan bersama sebagai masyarakat, bangsa dan Negara. Oleh sebab itu, mereka umumnya bersikap pro dan bersedia membantu upaya pemerintah menanggulangi korupsi

4. Pengetahuan masyarakat tentang perbuatan korupsi yang meningkat menumbuhkan keprihatinan dan sikap anti terhadap korupsi. Karena itu di masyarakat tumbuh kesadaran bahwa korupsi yang meningkat kuantitas dan kualitasnya menyebabkan kehidupan rakyat dan masyarakat makin sengsara, melemahkan sendi dan kekuatan hidup berbangsa, bernegara dan bermasyarakat. Pengetahun, sikap, dan kesadaran mereka yang tinggi terhadap dampak yang ditimbulkannya; membangkitkan respon yang positif dan besar terhadap upaya pemerintah menanggulangi tindak korupsi. Mereka bersedia mendukung dan berpartisipasi terhadap upaya pemerintah tersebut, terlebih jika mendapat jaminan perlindungan hukum yang menambah rasa aman.

Masyarakat mengetahui tentang tindak korupsi yang meluas saat ini. Mereka bersikap kritis terhadap korupsi, karena berpengaruh dan berdampak negatif terhadap usaha untuk meningkatkan kualitas kehidupannya. Korupsi merugikan masyarakat, dan kondisi kehidupan berbangsa dan bernegara. Oleh sebab itu, masyarakat memberikan respon kritis dan mendukung upaya pemerintah memberantas korupsi. Mereka bersedia dan berperan membantu untuk meningkatkan pelaksanaa program pemberantasan korupsi; sebagian besar di antara mereka ingin berpartisipasi aktif dengan mengharapkan jaminan perlindungan keamanan dirinya dari pemerintah.

\section{E. Saran}

1. Hasil penelitian menunjukkan pengetahuan masyarakat tentang perbuatan korupsi yang luas, sikap prihatin dan anti terhadap perbuatan tersebut, kesadaran dan persepsi masyarakat akan dampak negatif dan bahaya perbuatan korupsi yang besar terhadap penderitaan hidup masyarakat, melemahkan sendi-sendi kehidupan masyarakat, berbangsa dan bernegara serta respon yang besar dan positif terhadap usaha pemerintah menanggulangi korupsi;

2. Tingkat pengetahuan keluarga dan masyarakat yang tinggi terhadap korupsi, sikapnya yang menolak tindakan koruptif, kesadaran yang tinggi terhadap bahaya korupsi bagi kehidupan berbangsa, bernegara dan bermasyarakat, serta tanggapannya yang positif terhadap upaya pemerintah (lewat KPK) dalam memberantas korupsi perlu diapresiasi dan diposisikan sebagai modal social untuk mendukung dan mengelola program pemberantasan korupsi secara efisien dan efektif.

3. Hasil penelitian ini gayut dengan harapan dan himbauan Komisi Pemberantasan Korupsi dan institusi pemerintah lainnya yang relevan berperan dalam menanggulangi korupsi. Maka penelitin menyarankan kepada pemerintah untuk mempertimbangkannya sebagai salah satu bahan pertimbangkan kebijakan public tentang peran dan partisipasi keluarga dan masyarakat dalam ikut membantu upaya pemberantasan korupsi dalam bentuk tindakan preventif, dan mendukung tindakan bersifat kuratif. 
4. Berdasarkan hasil penelitian ini, disarankan untuk dilakukan pengembangan jaringan penelitian lanjut dan kerjasama dengan lembaga pemerintah dan non pemerintah untuk merealisasi gerakan dan partisipasi masyarakat dalam mendukung upaya pemerintah menanggulangi korupsi.

5. Mendiseminasikan hasil penelitian pada seminar, publikasi dan mengundang kerjasama dari semua pihak yang melakukan kajian, penelitian dan organisasi praktisi penanggulangan korupsi untuk bersinergi dan menguatkan peranan serta partisipasi masyarakat dalam penanggulangan korupsi.

\section{F. Persantunan}

Penelitian 'Studi Pemahaman Masyarakat tentang Tindak Korupsi' bertujuan untuk mengetahui sebaran pengetahuan, sikap, kesadaran, dan responnya terhadap perbuatan korupsi di masyarakat. Pelaksanaannya dilakukan di Kabupaten Klaten, Kecamatan Pedan di Desa Kedungan; Kabupaten Sragen, Kecamatan Tanon di Desa Gabugan; dan di Kelurahan Kerten, Kecamatan Laweyna di Kota Surakarta.
Hasil penelitian ini dilaporkan pada Rektor dan Ketua Lembaga Penelitian dan Pengabdian Pada Masyarakat Universitas Sebelas Maret, Surakarta. Pelaksanaan penelitian ini telah berlangsung baik dan lancar berkat bantuan dan dukungan jajaran pimpinan Kabupatn dan Kota, kecamatan dan desa-desa/kelurahan tersebut di atas; secara khusus bantuan telah diberikan langsung berupa tanggapan dari warga masyarakat. Oleh karena itu, pada kesempatan ini kami mengucapkan terima kasih atas dukungan dan bantuan yang telah dibarikan, pada:

1. Rektor Universitas Sebelas Maret

2. Ketua Lembaga Penelitian dan Pengabdian pada masyarakat

3. Bupati dan Walikota serta Jajaran Pemerintahan di Kabupaten Klaten, Sragen dan Kota Surakarta, Kepala Desa Kedungan, Gabugan dan Kepala Kelurahan Kerten

4. Segenap masyarakat Desa Kedungan, Gabugan dan Kelurahan Kerten

5. Dan semua pihak yang telah membantu pelaksanaan penelitian ini yang belum kami sebutkan satu per satu 


\section{daftar Pustaka}

Adjie Suradji. 2012. "Pemimpin, Korupsi dan Tanggung Jawab", Jakarta: harian Kompas, Sabtu 13 Oktober 2012

Ainan. 1997. dalam Bunga Rampai Etika Pegawai Negeri, eds. Mochtar Lubis. Jakarta: Bhratara Karya Aksara

Alatas. 1987. Korupsi : Sifat, Sebab dan Fungsi. Jakarta: LP3eS

Anonim. 1999. Undang-Undang Nomer 31 Tahun 1999 tentang Pemberantasan Tindak Pidana Korupsi, yang telah diubah dengan Undang-Undang Nomer 20 Tahun 2001 Tentang Perubahan Atas Undang-Undang Nomer 31 Tahun 1999 tentang Pemberantasan Tindak Pidana Korupsi

Djulianto. 2009. dalam 'A to Z Korupsi : Menumbuhkan Spirit Anti Korupsi' eds. Ulul Albab. Surabaya: Jaringpena

Jonathan Sarwono. 2002. Mixed Methods: cara Menggabung Riset Kuantitatif dan Riset Kualitatif Secara Benar

Kluckhon. 1980. Mentalitas dan Pembangunan ed. Koentjoroningrat. Jakarta : Gramedia

Mullan, Mc. 1997. dalam Bunga Rampai Etika Pegawai Negeri, eds. Mochtar Lubis. Jakarta: Bhratara Karya Aksara

Poloma, Margaret M. 1994. Sosiologi Kontemporer. Jakarta: RajaGrafindo Persada dan Yayasan Solidaritas Gadjah Mada

RB. Soemanto. 2006. Sosiologi Keluarga. Jakarta: Penerbit Universitas Terbuka

Raho, Bernard, SVD. 2007. Teori Sosiologi Modern. Jakarta: Prestasi Pustaka Publishers

Ritzer, George. 1980. Sosiologi Ilmu Pengetahuan Berparadigma ganda, Penyadur Alimandan. Jakarta: Penerbit Rajawali

Sjafri, Sairin. 2002. Perubahan Sosial Masyarakat Indonesia. Persepektif Anthropologi, yogyakarta: Pustaka Pelajar.

http:/fisip-Erika.repository.korupsi.usu.ac.id., diakses pada [13 Oktober 2011] 